Vol 7, No 2, Oktober 2012: $116-127$

\title{
PENGGUNAAN PEMBELAJARAN KOOPERATIF TYPE INQUERY UNTUK MENINGKATKAN HASIL BELAJAR UNSUR SERAPAN BAHASA INDONESIA SISWA KELAS XI SMA NEGERI 4 PEKANBARU

\author{
Raja Usman
}

Dosen FKIP Universitas Terbuka pada UPBJJ Pekanbaru

\begin{abstract}
ABSTRAK
Penelitian ini bertujuan mendeskripsikan penerapan penggunaan unsur serapan melalui metode inquery di SMA Negeri 4 Pekanbaru. Metode penelitian adalah metode inquery karena penelitian berharap bahwa metode ini siswa dapat menemukan langsung masalah yang dipelajari siswa. Hasil belajar sebelum penelitian adalah sangat rendah yaitu ketuntasan sebanyak 13 orang 38,24\% setelah diadakan perbaikan pada siklus I yang lulus sebanyak 14 orang 41,18\% dan pada siklus II lulus 30 orang $88,24 \%$. Yang tidak tuntas masih ada 4 orang yaitu $11,76 \%$.
\end{abstract}

Kata kunci : Penerapan Metode Inquery-Unsur Serapan-Hasil Belajar

\section{PENDAHULUAN}

Bahasa memegang peranan penting dalam berkomunikasi. Di mana-mana orang berkomunikasi atau menyampaikan gagasannya dengan berbahasa. Dalam perkembangannya, bahasa Indonesia diperkaya dengan bahasa-bahasa lain. Artinya bahasa Indonesia menyerap unsur dari berbagai bahasa, baik dari bahasa daerah maupun dari bahasa asing, seperti Sansekerta, Arab, Porutgis, Belanda, Cina dan Inggris.

Unsur serapan yang sudah lazim dieja sesuai dengan ejaan bahasa Indonesia tidak perlu diubah. Misalnya: 1) bengkel, kabar, nalar, paham, perlu, sirsak; 2) sekalipun dalam ejaan yang disempurnakan huruf $Q$ dan $X$ diterima sebagai abjad bahasa Indonesia, unsur yang mengandung kedua huruf itu diindonesiakan menurut kaidah. Kedua huruf itu dipergunakan dalam penggunaan tertentu saja, seperti dalam pembedaan nama dan istilah khusus. Di samping pegangan untuk penulisan serapan tersebut di atas, di bawah ini didaftarkan juga akhiran-akhiran asing serta penyesuaiannya dalam bahasa Indonesia. Akhiran itu diserap sebagai kata yang utuh. Kata seperti standardisasi, efektif, dan implementasi diserap secara utuh disamping kata standar, efek, dan implemen Salinan sesuai dengan aslinya Biro Hukum dan organisasi Depdiknas, Kepala Biro Hukum dan Organisasi Dr. Andi Pangerang Moenta, SH., MH, DFM. 
Penggunaan pembelajaran kooperatif type inquery untuk meningkatkan hasil belajar unsur serapan bahasa indonesia siswa kelas xi sma negeri 4 pekanbaru

(Raja Usman)

Unsur serapan merupakan mata pelajaran yang sangat penting dikuasai oleh siswa. Pembelajaran tercantum dalam pokok bahasa unsur serapan bahasa Indonesia. Dalam Pedoman Ejaan yang Disempurnakan unsur serapan tersebut dimasukkan ke dalam kata dan istilah yang baru ke dalam bahasa Indonesia. Dalam kenyataannya masih masih banyak siswa yang menggunakan unsur serapan yang tidak baku.

Untuk itu guru merupakan sumber daya manusia yang memegang peranan penting untuk proses pembelajaran. Dalam menciptakan proses pembelajaran guru diharapkan mampu untuk membangkitkan aktivitas dan minat siswa dalam kondisi yang benar-benar belajar. Siswa diberi kesempat mempelajari konsep dan teori tentang unsur serapan. Tujuan akhir dari proses tersebut siswa mengetahui dan dapat menggunakan unsur serapan sebagai alat komunikasinya, selain itu siswa juga memperoleh hasil belajar yang baik. Untuk mencapai hasil belajar yang baik, guru harus mengontrol secara cermat kegiatan siswa karena siswa mempunyai kemampuan yang beragam.

Menurut Peraturan Pemerintah No. 19 tahun 2005 tentang standar Nasional Pendidikan diantarnya: Kurikulum dilaksanakan dalam suasana hubungan siswa dan guru yang saling menerima dan menghargai, akrab, terbuka dan hanya dengan psinsip; dibelakang memberikan daya dan kekuatan, di tengah membangun semangat dan prakarsa, di depan memberi contoh.

Proses pembelajaran yang dilakukan guru harus dapat memberikan kesempatan kepada siswa dalam mempelajari kata-kata dan unsur serapan. Dengan memberikan kesempatan siswa akan lebih banyak menggali perkembangan katakata yang telah dibakukan dalam pembelajaran bahasa Indonesia. Siswa akan lebih mendalam pengetahuannya dan dapat memahami serta berperan aktif dalam menggunaan kata-kata atau unsur serapan yang telah ada. Pengetahuan yang dimilikinya akan mendukung untuk mengembangkan kemampuan, sikap dan ketrampilan siswa dalam menerapkan bahasa tersebut.

Dari pengalaman hasil belajar siswa masih rendah ini disebabkan beberapa faktor. Faktor guru, dalam proses pembelajaran masih menjalankan pelaksanaaan berpusat pada guru. Guru mengajar kurang memperhatikan kemampuan berfikir siswa karena setiap siswa mempunyai kemampuan yang berbeda-beda. Kegiatan pembelajaran selalu diawali dengan memberikan penjelasan tentang pengertian. 
Guru memberikan tugas berupa Lembar Kerja Siswa (LKS) kegiatan tersebut sampai selesai. Guru lupa memberikan motivasi belajar kepada siswa. Proses kegiatan inti ini, guru selalu menggunakan metode ceramah, tanya jawab, dan tugas. Kemudian menjelaskan apa yang harus dikerjakan oleh siswa. Setiap kali pertemuan proses pembelajaran seperti ini selalu berulang-ulang dipermukaan sehingga timbul rasa bosan mereka dan proses belajar tidak aktif. Faktor siswa adalah selalu menunggu perintah guru untuk mengerjakan soal yang tercantum pada Lembar Kerja Siswa (LKS). Mereka menjadi pasif karena faktor di luar siswapun tidak mendukung agar mereka bisa berbuat banyak sebab mereka telah terbiasa untuk mendapat bantuan jawaban dari teman-teman yang lebih pintar. Selain itu mereka lebih suka meniru hasil yang telah dikerjakan teman-teman mereka.

Untuk mengatasi proses kegiatan pembelajaran perlu diambil langkah untuk mengubah metode dalam pembelajaran. Untuk menekankan kepada proses berpikir secara kritis dan analitis perlu metode Inkueri (kegiatan menemukan), artinya metode inkuiri berupaya menanamkan dasar-dasar berfikir ilmiah pada diri siswa, sehingga dalam proses pembelajaran ini siswa lebih banyak belajar sendiri, mengembangkan kreativitas dalam memecahkan masalah. Siswa sebagai subjek bukan objek. Sedangkan guru sebagai pembimbing dan fasilitator. Guru memilih masalah yang perlu disampaikan kepada kelas untuk dipecahkan. Kemudian guru menyediakan sumber belajar bagi siswa. Siswa dapat temuan-temuan yang bermakna untuk menghasilkan temuannya. Jadi siswa benar-benar menemukan sendiri fakta yang ada dan tidak hanya mengingat hasil yang diperolehnya dari fakta tersebut.

Roestiyah (2008) mengatakan inkuiri adalah istilah dalam bahasa Inggris; ini merupakan suatu teknik atau cara yang digunakan guru untuk mengajar di depan kelas. Selanjutnya teknik inkueri memiliki keunggulan yang dapat dikemukakan sebagai berikut (Roestiyah . (2008): 1. dapat membentuk dan mengembangkan "selconcept" pada diri siswa, sehingga siswa dapat mengerti tentang konsep dasar dan ide-ide lebih baik; 2. membantu dalam menggunakan ingatan dan transfer pada situasi proses belajar yang baru; 3. mendorong siswa untuk berpikir dan bekerja atas inisiatifnya sendiri, bersikap objektif, jujur, dan terbuka; 4. mendorong siswa untuk berpikir intuitif dan merumuskan hipotesisnya sendiri.; 5. memberikan kepuasan yang bersifat lebih merangsang; 6 . situasi proses belajar menjadi lebih merangsang; 7 dapat mengembangkan bakat atau kecakapan idividu; 8. Memberikan kebebasan siswa untuk belajar sendiri; 9. siswa dapat menghindari cara-cara belajar yang 118 
Penggunaan pembelajaran kooperatif type inquery untuk meningkatkan hasil belajar unsur serapan bahasa indonesia siswa kelas xi sma negeri 4 pekanbaru

(Raja Usman)

tradisional; 10. dapat memberikan waktu pada siswa secukupnya sehingga mereka dapat mengasimilasi dan mengakomodasi informasi. Artinya dengan adanya dorongan dari diri siswa sendiri, maka proses berpikir, bakat, kebiasaan belajar siswa akan lebih baik cara belajarnya karena mereka mempunyai inisiatif sendiri, objektif dan jujur sehingga waktu yang digunakan dapat diatur dan dapat juga mengasimilasi serta mengakomodasi informasi yang lebih jelas.

Menurut Galo (2002) sasaran utama inkuiri dalam kegiatan mengajar adalah 1) keterlibatan siswa secara maksimal dalam proses kegiatan belajar. Kegiatan belajar di sini adalah kegiatan mental, intelektual dan social emosional; 2) keterarahan kegiatan secara logis dan sistematis pada tujuan pengajaran; 3) mengembangkan sikap pada diri sendiri (self belief) pada diri siswa tentang apa yang ditemukan dalam proses inquery. Selanjutnya Galo (2002) menyatakan bahwa peranan guru dalam menciptakan kondisi inkuiri sebagai berikut: 1) motivator, yang memberikan rangsangan supaya siswa aktif dan gairah berpikir; 2) fasilitator, yang menunjukkan jalan keluar jika ada hambatan dalam proses berpikir siswa; 3) penanya, untuk menyadarkan siswa dari kekeliruan yang mereka perbuat dan memberikan keyakinan pada diri sendiri; 4) administrator, yang bertanggung jawab terhadap seluruh kegiatan di dalam kelas; 5) pengarah, yang meminpin arus kegiatan berpikir siswa pada tujuan yang diharapkan; 6) manajer, yang mengelola sumber belajar,,waktu danorganisasi kelas; 7) reward, yang member penghargaan pada prestasi yang dicapai dalam rangka peningkatan semangatr heuristik pada siswa.

Pembelajaran inkuiri dapat dilaksanakan secara kelompok. Menurut Slavin (2009) pembelajaran kooperatif beranggotakan antara 4 - 5 orang yang heterogen menurut tingkat prestasi, jenis kelamin, dan suku. Artinya perbedaan itu diharapkan dapat membantu anggota dalam kelompok. Siswa yang berkemampuan tinggi dapat menunjukkan siswa yang berkemampuan rendah, karena keberhasilan kelompok sangat diperhatikan.

Aunurrahman (2009) ada beberapa langkah dalam melaksanakan metode inkuiri yaitu: 1) mempertentangkan suatu masalah. Pada tahap ini guru menjelaskan prosedur inkuiri dan menjelaskan peristiwa-peristiwa yang bertentangan; 2) siswa melakukan pengumpulan data serta melakukan klarifikasi; 3) siswa melakukan pengujian hipotesis; 4) siswa mengorganisasikan data memberikan penjelasan; 5) 
Vol 7, No 2, Oktober 2012: $116-127$

siswa melakukan analisis strategi inquery dan mengembangkan secara lebih efektif. Dalam urutan tersebut siswa memiliki kemampuan melakukan pekerjaan. Mereka tahu prosedur sesuai kronologis peristiwa-peristiwa seperti mengumpulkan data, serta mengidentifikasi, menguji hipotesis, melakukan analisis secara efektif dan efisien.

Menurut Dimyati dan Mudjiono (2006) hasil belajar merupakan hasil dari suatu interaksi tindak belajar dan tindak mengajar. Dari sisi guru tindakan mengajar diakhiri dengan proses evaluasi hasil belajar sedangkan dari siswa hasil belajar merupakan puncak proses belajar. Nana Sudjana (2004) mengatakan bahwa hasil belajar adalah kemampuan-kemampuan yang dimiliki seorang siswa setelah ia menerima pengalaman belajar. Artinya kemampuan yang dimiliki seorang siswa setelah ia menerima perlakuan dari pengajar (guru). Artinya pengetahuan tidak akan dating sendiri jika tidak ada proses pembelajaran karena proses tersebutlah akan menciptakan hasil belajar.

Hasil belajar siswa dipengaruhi oleh kemampuan siswa dan kualitas pengajaran. Artinya kemampuan dasar guru baik dibidang kognetif, sikap dan prelaku. Hasil belajar adalah suatu kemampuan yang diperoleh siswa dalam prose bpembelajaran sehingga siswa tersebut mengalami perubahan dalam bidang pengetahuan, sikap dan ketrampilan.

Penelitian ini peneliti membatasi masalah pada penggunaan pembelajaran kooperatif type inkuiri memungkinkan dapat meningkatkan hasil belajar siswa. sedangkan rumusan masalah dalam penelitian ini apakah Penggunaan Pembelajaran Kooperatif Type Inkuiri Dapat Meningkatkan Hasil Belajar Siswa Kelas XI SMA Negeri 4 Pekanbaru. Tujuan penelitian ini mendeskripsikan penggunaan pembelajaran kooperatif type inkuiri dan membantu guru dalam proses pembelajaran bahasa dan pembelajaran yang lain. Dapat membantu siswa menambah pengalaman cara belajar inkuiri dan menambah hasil belajar.

\section{METODE PENELITIAN}

Penelitian ini merupakan Penilitian Tindakan Kelas (PTK) yang dilaksanakan dua siklus. Masing-masing siklus mempunyai tahapan. Perencanaan, Pelaksanaan, Lembar Observasi dan Refleksi. Subjek penelitian ini adalah guru dan siswa kelas II SMA Negeri 4 Pekanbaru. Teknik pengambilan data adalah observasi, daftar pelaksanaan, tes instrument pengumpulan data digunakan pedoman wawamcara, 120 
Penggunaan pembelajaran kooperatif type inquery untuk meningkatkan hasil belajar unsur serapan bahasa indonesia siswa kelas xi sma negeri 4 pekanbaru

(Raja Usman)

penilaian menggunakan APKG 2 (Alat Penilaian Kegiatan Guru 2), aktivitas belajar siswa serta tes akhir. Waktu pelaksanaan penelitian bulan Oktober 2009 sampai Desember 2009.

Sebelum penulis melaksanakan penelitian, peneliti mengadakan koordinasi dengan guru yang mengajarkan pembelajaran bahasa Indonesia di SMA Negeri 4 Pekanbaru. Guru menegaskan bahwa unsur serapan telah dipelajari sejak dibangku SMP. Siswa telah mengetahui perubahan unsur serapan baik dari segi huruf maupun kata. Perubahan huruf dan kata serapan yang telah dibakukan selalu ditetapkan dalam penggunaannya.

Pertama pelaksanaan awal proses pembelajaran meliputi: a) guru dapat menarik perhatian siswa agar mereka mengikuti proses pembelajaran dengan baik sesuai dengan prosedur pembelajartan; b) guru melakukan apersepsi materi lama dan materi baru untuk melancarkan proses kegiatan pembelajaran; c) guru memberikan motivasi untuk mengaktifkan siswa; d) menjelaskan ruang lingkup materi yang dibahas; e) menjelaskan relevansi dan manfaat materi yang akan dibahas; f) menjelaskan kopentensi yang akan dicapai serta mereview materi sebelumnya.

Kedua pelaksanaan kegiatan inti guru telah melakukan kegiatan tersebut dengan menggunakan pendekatan kooperatif.type inquery. Langkah-langkah pembelajaran disesuai dengan proses pembelajaran kooperatif type inquery. Menurut Nurulhayati. (2002) bahwa pembelajaran kooperqatif melibatkan partisifasi siswa dalam satu kelompok kecil untuk saling berinteraksi. Selanjutnya pembelajaran kelompok adalah rangkaian kegiatan belajar yang dilakukan oleh siswa dalam kelompok-kelompok tertentu untuk mencapai tujuan pembelajaran yang telah dirumuskan (Wina Sanjaya 2006). Artinya siswa dikelompokan dalam pembelajaran guna menciptakan peran aktif siswa mempelajari pokok bahasan yang disajikan baik secara mandiri maupun secara kelompok. Mereka salaing menunjukkan dan saling membantu untuk menyelesaikan pekerjaannya sesuai dengan kompetensi yang diharapkan. Selain itu siswa dapat meningkatkan hasil belajar mereka.

Seperti yang telah disebutkan di atas, kelompok terdiri dari 4-5 orang yang heterogen menurut prestasi, jenis kelamin, dan suku. Maksud pembagian tersebut agar siswa yang pandai dapat memberitahukan kepada siswa yang kemampuannya rendah. Dalam proses pembelajaran mereka telah diberikan Lembar Kerja Siswa 
Vol 7, No 2, Oktober 2012: $116-127$

(LKS). Setiap siswa harus mengerjakan LKS sesuai dengan perintah kerja. Guru menyampaikan langkah-langkah dalam proses pembelajaran 1) siswa mengadakan observasi tentang bacaan, 2) membuat pertanyaan terhadap bahan yang disajikan, 3) siswa disuruh mengajukan dugaan-dugaan (hipotesis) 4) guru mengumpulkan data, menyimpulkan hasil yang diperoleh dalam pembelajaran. Pada kegiatan menyimpulkan guru menyuruh siswa a) merumuskan masalah; b) mengamati atau melakukan observasi; c) menganalisis dan menyajikan hasil dalam tulisan; d) mengkomunikasikan atau menyajikan hasilnya pada pihak lain (pembaca, teman sekelas, guru, audiens lainnya).

Setelah diadakan pengelompokan dan berdiskusi hasil yang dikerjakan mereka, setiap kelompok mempresentasikan hasil diskusi kepada kelompok lain sehingga mendapatkan kesimpulan bersama. Dalam hal ini guru dalam kegiatan pembelajaran mengamati proses keaktifan siswanya. Setelah itu guru merefleksi diri untuk mendeskripsi proses pembelajaran, menilai atau mengevaluasi hasil pembelajaran dan memperbaiki kelemahan yang ada pada siklus I.

Menurut Oemar Hamalik (2007) menjelaskan bahwa proses inkuiri menuntut guru bertindak sebagai fasilitator, nara sumber dan penyuluhan.kelompok. Para siswa didorong untuk mencari pengetahuan sendiri, bukan dijejali dengan pengetahuan. Strategi instruksional dapat berhasil bila guru memperhatikan kriteria sebagai berikut: 1) .mendifinisikan secara jelas topik inkuiri yang dianggap bermanfaat bagi siswa; 2) membentuk kelompok-kelompok dengan memperhatikan keseimbangan aspek akademik dan aspek social; 3) menjelaskan tugas dan menyediakan balikan kepada kelompok dengan cara yang responsive dan tepat waktu; 4) Intervensi untuk meyakinkan terjadinya interaksi antara pribadi secara sehat damn terdapat dalam kemajuan pelaksanaan tugas; 5) melakukan evaluasi denganm berbagai cara untuk menilai kemajuan kelompok dan hasil yang dicapai.

Dari uraian di atas dalam proses pembelajaran dalam dilakukan sebagai berikut: a) guru menginformasikan unsur serapan yang digunakan sambil menggali pengetahuan dan pengalaman siswa melalui pertanyaan dan tanya jawab penggunaan unsur serapan, b) guru membagi siswa dalam kelompok gunanya mereka bebas untuk mengeluarkan pendapat dan bertanya bila ada yang tidak dimengerti, kecuali dalam kelompok tidak ada yang bias menjawab, pertanyaan diarahkan kepada guru; c) masing-masing siswa mengerjakan soal pada Lembar Kerja Siswa (LKS), d) duduk berkelompok sesuai dengan tugas yang diberikan, d) 122 
Penggunaan pembelajaran kooperatif type inquery untuk meningkatkan hasil belajar unsur serapan bahasa indonesia siswa kelas xi sma negeri 4 pekanbaru

(Raja Usman)

guru memandu kegiatan apabila ada masalah yang dihadapi siswa guru dapat membantu mengarahkan bagaimana cara penyelesaiannya. Setelah selesai pelaksanaan kegiatan ini semua kelompok akan mempersentasikan hasil yang diperoleh. Kelompok penyajikan akan menjawab setiap pertanyaan, saran dan tanggapan yang diberikan kepada kelompoknya. Setelah itu guru mengadakan tes untuk mendapatkan hasil belajar siswa.

Ketiga selama proses pembelajaran pada kegiatan kedua, guru mengamati aktivitas siswa dalam mengerjakan soal maupun berdiskusidan.. Dalam pengamatan ini guru memperhatikan siswa yang benar-benar aktif. Biasanya siswa yang berpengetahuan tinggi dari teman-temannya. Siswa yang berkembampuan rendah atau biasa-biasa selalu menunggu hasil yang dikerjakan oleh temannya yang berpengetahuan tinggi. Ada juga siswa yang pura-pura aktif sebanarnya mereka tidak aktif.

Keempat setelah diadakan tindakan, guru merefleksi diri dengan singkat mendeskripsikan kegiatan yang telah dilaksanakan, mengevaluasi hasil observasi, menganalisis hasil pembelajaran dan memperbaiki kelemahan untuk siklus berikutnya.

Pada siklus II prosedur pembelajaran pada awal pelaksanaan dilakukan apersepsi, mengabsen siswa, menjelaskan rtuang lingkup pembelajaran, memotivasi dan menjelaskan tujuan kompetensi yang akan dicapai.

Kompetensi yang harus dimiliki oleh siswa yaitu bagaiamana caranya mengumpulkan data sekaligus mengkelasifikasikannya. Dari data yang telah diperoleh siswa mengajukan dugaan sementara atau hipotesis. Hasil yang diperoleh dari hipotesis berguna untuk langkah kerja siswa selanjutnya. Dari sini siswa mengorganisasikan dan menjelaskan pembelajaran unsur serapan. Setelah itu siswa melakukan analisis strategi inkuiri (penemuan) dan mengembangkankannya lebih efektif. Pada siklus I hal yang serupa juga dilakukan siswa, namun pada siklus I siswa masih banyak mengalami keragu-raguan dalam mengerjakan pekerjaannya. Setelah mendapatkan bimbingan dari guru pada siklus II masalah keragu-raguan tidak terdapat keraguan baik dari guru maupun dari siswa sendiri. Dan kegiatan siklus II ini lebih memantapkan pekerjaan lebih efisien dan efektif. 
Vol 7, No 2, Oktober 2012: 116 - 127

\section{HASIL DAN PEMBAHASAN}

Pada langkah-langkah pembelajaran, siswa masih merasa ragu dan bingung kegiatan yang harus dilakukan seperti observasi, membuat pertanyaan, mengajukan dugaan sementara, mengumpulkan hasil serta menyimpulkan hasil pembelajaran. Pelaksanaan siklus pertama tidak begitu lancar karena guru masih belum jelas memberikan pengarahan apa yang harus dilakukan siswa. Setelah siklus kedua baik guru maupun soswa dapat mengikuti kegiatan belajar dengan baik dan lancer. Karena langkah-lanmgkah pada pertemuan kedua siswa telah mendapatkan bimbingan Dalam bacaan sebenarnya siswa disuruh mencari kata unsur serapan. Pada kegiatan menyimpulkan siswa merumuskan masalah, mengamati, menganalsis, menyajikan hasil dalam tulisan dan mengkomunikasikan hasil pihak lain.

Sebelum pelaksanaan klegiatan pembelajaran pada siklus pertama dan kedua, siswa diberikan tes untuk mengetahui sejauhmana pengetahuan siswa terhadap pokok bahasan yang akan diajarkan. Hasil tes yang diperoleh pada tes awal dapat dilihat pada Tabel 1

Tabel 1. Hasil Tes Awal Unsur Serapan Siswa Kelas II SMA Negeri 4 Pekanbaru

\begin{tabular}{|l|l|c|c|}
\hline \multicolumn{1}{|c|}{ No } & \multicolumn{1}{|c|}{ Rentang Nilai } & Nilai Awal & Persentase \\
\hline 1 & $90-100$ & - & - \\
\hline 2 & $80-99.99$ & 4 & $11.76 \%$ \\
\hline 3 & $70-89.99$ & 9 & $26.47 \%$ \\
\hline 4 & $60-69.99$ & 6 & $17.65 \%$ \\
\hline 5 & $50-59.99$ & 6 & $17.65 \%$ \\
\hline \multicolumn{2}{|l|}{ Nilai Rata-rata } & 9 & $26.47 \%$ \\
\hline \multicolumn{2}{|l|}{ KKM } & 56,47 & \\
\hline \multicolumn{2}{|l|}{ Tidak Tuntas } & 70 & \\
\hline
\end{tabular}

Setelah diadakan tes, nilai yang diperoleh sebelum proses pembelajaran sesuai dengan rentang nilai untuk melihat pengetahuan mereka tentang unsure serapan yaitu rentang nilai 90 -100 tidak ada, rentang kisaran 80 - 89.99 sebanyak 4 orang $(11,76 \%)$, rentang nilai kisaran 70 - 89,99 sebanyak 9 orang $(26.47 \%)$, rentang nilai kisaran 60 - 69,99 sebanyak 6 orang $(17,65 \%)$, rentang nilai kisaran 50 - 59,99 sebanyak 6 orang $(17,65 \%)$ dan oo - 40.00 sebanyak 9 orang $(26.47 \%)$. 
Jika ditinjau dari ketuntasan maksimal pada siswa yang telah tuntas hanya mencapai 13 orang 38.24\%, sedangkan yang tidak tuntas sebanyak 21 orang 61,76\%.

Setelah diadakan proses pembelajaran pada siklus I dan siklus II dapat dilihat pada tabel 2.

Tabel 2. Hasil Penilaian Unsur Serapan siswa Kelas II SMA Negeri 4 Pekanbaru

\begin{tabular}{|l|l|c|c|c|c|}
\hline No & \multicolumn{1}{|c|}{ Renang Nilai } & $\begin{array}{c}\text { Nilai Siklus } \\
\text { II }\end{array}$ & $\%$ & $\begin{array}{c}\text { Nilai } \\
\text { Siklus II }\end{array}$ & \% \\
\hline 1 & $90-100$ & & & 9 & 26.47 \\
\hline 2 & $80-89.99$ & 3 & 8.82 & 9 & 26.47 \\
\hline 3 & $70-79.99$ & 11 & 32.35 & 12 & 35.29 \\
\hline 4 & $60-69.99$ & 17 & 50 & 4 & 11.76 \\
\hline 5 & $50-59.99$ & 3 & 8.83 & - & \\
\hline & $\ldots .-49.99$ & & & - & \\
\hline & Nilai Rata-rata & 64.12 & & 76.76 & \\
\hline & KKM & 70 & & 70 & \\
\hline & Tuntas & 41.18 & & 88.24 & \\
\hline & Tidak Tuntas & 58.82 & & 11.76 & \\
\hline
\end{tabular}

Pelaksanaan siklus pertama rentang nilai 88. - 89,99 sebanyak 3 orang (8.82\%), rentang nilai $70-89,99$ sebanyak 11 orang (32.35\%), rentang nilai 60 69,99 sebanyak 17 orang (50\%) dan rentang nilai 50 - 59,99 sebanyak 3 orang (8.83\%). Selanjutnya pada siklus II rentang nilai 90 - 100 sebanyak 9 orang, $(26,47 \%)$, rentang nilai 88 - 89,99 sebanyak 9 orang $(26,47 \%)$, rentang nilai 70 79,99 sebanyak 12 orang (35,29\%), rentang nilai 60 - 69,99 sebanyak 4 orang $(11,76 \%)$..

Pada siklus pertama ketuntasan belajar siswa 14 orang $41.17 \%$ dan tidak tuntas sebanyak 20 orang $58,82 \%$ sedangkan pada siklus II yang tuntas sebanyak 30 orang $88,24 \%$.. 
Vol 7, No 2, Oktober 2012: $116-127$

Selanjutnya dapat kita lihat berdasarkan criteria penilai seperti tabel berikut:

Tabel 3. Hasil belajar Siswa Kelas II Siklus I dan II

\begin{tabular}{|l|l|l|c|c|c|}
\hline No & Rentang Nilai & Kategori Nilai & Nilai Asal & $\begin{array}{c}\text { Nilai Siklus } \\
1\end{array}$ & Nilai Siklus II \\
\hline 1 & $90-100$ & Sangat Tinggi & & & 9 \\
\hline 2 & $80-99.99$ & Tinggi & 4 & 3 & 9 \\
\hline 3 & $70-89.99$ & Sedang & 9 & 11 & 12 \\
\hline 4 & $60-69.99$ & Rendah & 6 & 17 & 4 \\
\hline 5 & $50-59.99$ & $\begin{array}{l}\text { Sangat } \\
\text { Rendah }\end{array}$ & 6 & 3 & - \\
\hline \multicolumn{2}{|l|}{ Nilai rata-rata } & 9 & - & - \\
\hline \multicolumn{2}{|l|}{ KKM } & & 70 & 70 \\
\hline \multicolumn{2}{|l|}{ Tidak Tuntas } & 38.24 & 41.18 & 88.24 \\
\hline
\end{tabular}

Dari hasil nilai awal dan dua siklus berikutnya maka criteria nilai yang Sangat Tinggi 9 orang (26,47\%), Tinggi 9 orang (26.47\%), nilai Sedang sebanyak 12 orang (35,29\%), nilai Rendah 4 orang (11.76\%).

Dengan menggunakan pembelajaran kooperatif type inkuiri siswa bersemangat untuk mengikuti pembelajaran. Suasana belajar sangat menyenangkan, aktivitas siswa meningkat. Pengetahuan yang mereka peroleh semakin baik. Hal ini terbukti pada mulai dari pengambilan nilai (tes awal), siklus I dan siklus II, akan tetapi masih ada beberapa siswa yang belum mencapai ketuntasan karena terikat dengan rentang nilai (selisih beberapa angka) namun hal ini perlu diperhatikan guru.

Pada pelaksanaan siklus pertama masih banyak kekurangan guru. Guru masih terbawa-bawa dengan proses kegiatan pembelajaran yang biasa dilakukan. Namun setelah mempelajari kekurangan pada siklus pertama, guru dapat melaksanakan pembelajaran dengan lancer.

\section{KESIMPULAN}

Berdasarkan pembahasan dapat diambil kesimpulan:

1. Metode inkuiri dapat meningkatkan hasil belajar siswa kelas II SMA Negeri 4 Pekanbaru dari tes awal yang tuntas sebanyak 13 orang (38.24\%), tidak tuntas 21 orang (61.76\%) pada siklus I yang tuntas menjadi 14 orang $(41.17 \%$ dan tidak tuntas 20 orang (58.82\%) dan siklis II tuntas menjadi 30 orang $(88.24 \%)$ dan tidak tuntas 4 orang $(11.76 \%)$. 
2. Pembelajaran kooperatif type inkuiri dapat membantu guru dalam proses pembelajaran karena dilihat dari tes awal siswa yang belum mendapatkan ketuntasan belajar mengalami perubahan setelah proses pembelajaran siklus I dan II.

3. Setelah mendapakatkan informasi, siswa dapat mengetahui unsur serapan dapat dibuktikan adanya siswa yang mencapai predikat kreteria paling tinggi 9 orang, tiinggi 9 orang, sedang 12 orang.

Diharapkan bagi peneliti lanjutan dapat memperbaiki proses pembelajaran karena masih ada siswa yang belum mencapai hasil pembelajaran dikarenakan kekurangan beberapa angka sedsuai dengan rentang nilai yang telah ditentukan.

\section{DAFTAR PUSTAKA}

Aunurrahman., 2009. Belajar dan Pembelajaran. Bandung. Penerbit Alfabeta.

Depdiknas. 2005. Peraturan Pemerintah Republik Indonesia Nomor 19 Tahun 2005 Tentang Standar Pendidikan Nasional.

Dimyati dan Mudjiono., 2006. Belajar dan Pembelajaran. Jakarta.Rineka Cipta.

Gayo. W. 2002. Strategi Belajar Mengajar. Jakarta: Penerbit PT Gramedia

Nana. Sudjana, . http://www.wednesday. com, Juni 25. 2008. Peraturan pemerintah. 2005. Standar Nasional Pendidikan

Roestiyah, NK (2008) Strategi Belajar Mengajar. Jakarta. Penerbit Rineka Cipta..

Sanjaya, Wina: 2008. Strategi Pembelajaran Berorientasi Standar Proses Pendidikan. Jakarta: Kencana Prenada Media Group.

Oemar. Hamalik. 2001. Proses Belajar Mengajar. Jakarta. Bumi Aksara.

Slavin, Robert, C. 2009. Coopertif Learning, Teori Belajar Mengajar. Bandun: Remaja Rosdakarya. 